IZA DP No. 7770

Bride Price and Fertility Decisions: Evidence from Rural Senegal

Linguère Mously Mbaye

Natascha Wagner

November 2013 


\title{
Bride Price and Fertility Decisions: Evidence from Rural Senegal
}

\author{
Linguère Mously Mbaye \\ IZA \\ Natascha Wagner \\ ISS, Erasmus University Rotterdam
}

Discussion Paper No. 7770

November 2013

\author{
IZA \\ P.O. Box 7240 \\ 53072 Bonn \\ Germany \\ Phone: +49-228-3894-0 \\ Fax: +49-228-3894-180 \\ E-mail: iza@iza.org
}

Any opinions expressed here are those of the author(s) and not those of IZA. Research published in this series may include views on policy, but the institute itself takes no institutional policy positions. The IZA research network is committed to the IZA Guiding Principles of Research Integrity.

The Institute for the Study of Labor (IZA) in Bonn is a local and virtual international research center and a place of communication between science, politics and business. IZA is an independent nonprofit organization supported by Deutsche Post Foundation. The center is associated with the University of Bonn and offers a stimulating research environment through its international network, workshops and conferences, data service, project support, research visits and doctoral program. IZA engages in (i) original and internationally competitive research in all fields of labor economics, (ii) development of policy concepts, and (iii) dissemination of research results and concepts to the interested public.

IZA Discussion Papers often represent preliminary work and are circulated to encourage discussion. Citation of such a paper should account for its provisional character. A revised version may be available directly from the author. 


\section{ABSTRACT \\ Bride Price and Fertility Decisions: Evidence from Rural Senegal ${ }^{*}$}

This paper is the first to provide evidence about the relationship between bride price payments and fertility decisions in the African context. Remarkably, the results show that bride price payments reduce fertility pressure, with a woman reducing her number of children by 0.5 at the mean bride price. The results are robust to different tests that we conduct to address the potential endogeneity between bride price payments and fertility decisions. As possible transmission channels, we find that poor women and men with low levels of education are the most negatively affected by the tradition of bride price payments. Furthermore, a lower bride price payment increases fertility pressure in polygamous households and for arranged marriages, while the bride price payment has no effect on the couple's decisions concerning fertility in monogamous households and for love marriages. Consequently, given that bride price payments have less power over (economically) independent women, empowerment will give leeway to girls in traditional societies, even if the bride price system is not overturned.

JEL Classification: $\quad$ O12, Z13

Keywords: $\quad$ bride price, empowerment, fertility, marriage payments, Senegal

Corresponding author:

Linguère Mously Mbaye

IZA

P.O. Box 7240

53072 Bonn

Germany

E-mail: mbaye@iza.org

\footnotetext{
* We are grateful to Alpaslan Akay for valuable comments and suggestions on earlier versions of this paper. We also thank Kosali Simon, seminar and conference participants at the Midwestern Econometrics Group Meeting 2013, Indiana, USA; the 8th IZA/World Bank Conference on Employment and Development, Bonn, Germany; the 18th Annual Conference on Econometric Analysis and Policy Challenges in Africa, Accra, Ghana; the 88th Annual Conference of the Western Economic Association, Seattle, USA; the IZA Brown Bag Seminar, Bonn, Germany; and the 27th Annual Conference of the European Society for Population Economics, Aarhus, Denmark. We also acknowledge the participation of Jean-Louis Arcand, Marie-Charlotte Buisson and Samba Mbaye in the survey design and data collection. The usual disclaimer applies.
} 


\section{Introduction}

The bride price payment is a key element of the marriage contract in many subSaharan African countries, and particularly in Senegal. Contrary to a dowry payment, where the bride and her family give the marriage payment to the groom and his family, a bride price payment is defined as the money or wealth transfer given by or on behalf of the groom to the bride and her family upon the marriage of the couple $1^{1}$ Such a bride price system raises several concerns related to the economics of the marriage market, gender empowerment and intra-household bargaining power. We consider a woman's role in marriage as represented by the fertility decisions of the couple. Previous research for the case of Indonesia has shown that women who perceive more household assets as being their own have a greater say in fertility decisions (Beegle et al. 2001). Thus, fertility choices, as measured by the number of children at a given age, indicate female bargaining power and a woman's relative position within the household.

This paper provides an important contribution to the existing literature, as most studies about marriage payments have been carried out in South Asia. However, the African context of a bride price being paid is substantially different and the dynamics that apply in many parts of Asia cannot be extrapolated to the African continent. To the best of our knowledge, our study is the first large-scale analysis of bride price dynamics in Africa and the first that is interested in the relationship between bride price payments and fertility decisions in general, and in rural Africa in particular.

The ancient practice of bride price payments is performed in many sub-Saharan African countries $2^{2}$ In the specific case of Senegal, the value of the bride price

\footnotetext{
${ }^{1}$ In Senegal, the bride price is given to the bride and her family. In this context, it is impossible to disentangle the share of the marriage payment that goes to the bride herself from the share kept by her family. However, it is important to bear in mind that in African societies, and particularly in traditional societies, the group is more important and valued than the individual. Consequently, the specific share received by the bride is of minor importance, given that she makes part of her family of origin. What is of greater importance is the transaction from one family to another. Whenever the family of the bride receives a transfer, the bride will be considered as the one who received the payment and was valued by her in-laws, regardless of the share of the transfer over which she has direct control.

${ }^{2}$ The following sub-Saharan African countries practice bride price payments: Ghana, Kenya, Nigeria, Rwanda, Senegal, South Africa, Tanzania and Uganda. The list is non-exclusive. The aforementioned countries participated in an international conference about the system of bride
} 
is determined in negotiations between the two families. The bargaining process preceding a marriage might only involve the couple or even take into consideration advice given by the extended family. Before the actual marriage celebration, several consultative visits and mutual invitations take place between the future spouses and/or close family members. To conclude this period of negotiations, the bride's parents have to choose a date for the marriage ceremony and announce the desired value of the bride price, which can comprise cash and material goods such as furniture and jewels. Moreover, most of the Senegalese are Muslims and, according to the Islamic law, a minimum amount is necessary to validate the marriage. However, this amount is sufficiently low to only be of symbolic value (around FCFA 5,000 or EUR 8). It is common practice that people give a higher bride price than what is required by religion. Moreover, in sub-Saharan African countries, bride price payments result from tribal traditions and are practiced regardless of religious affiliation, with both Muslims and Christians adhering to these traditions. As a bride price exceeding the amount set by Islamic law is not fixed, its precise amount depends on the appreciation of the bride by both her family and in-laws, the bride's socio-economic conditions, her relative bargaining power, the prestige of both families as well as customary law. In the extreme case, the bride price payment asked for by the girl's family might be prohibitively high to prevent the union with an unpopular man. In a different context, the girl's family might abstain from any claim for altruistic reasons. Given that the actual negotiation is a dynamic process that depends upon the socio-economic conditions of the two families, the value of the realized bride price payment varies considerably across couples ${ }^{3}$ For the purpose of this study, we employ a unique panel dataset of 2,241 observations, which allows us to quantify the effect of the bride price on the number of children that a woman gives birth to. We find a negative relationship price payments in Uganda in 2004.

${ }^{3} \mathrm{~A}$ historical overview of marriage laws in early African societies reveals that marriage payments have not always been perceived as a "bride price". According to Kanji and Camara (2000), the term "prenuptial gift" is more appropriate than bride price. Traditionally, marriage payments were not viewed as a price or compensation. Such transfers were of symbolic nature, representing the engagement of the groom towards his bride and her family. Nonetheless, these nuptial transfers were interpreted as a bride price as time evolved, with the concept further shaped by traditional, religious and political influences. The aim of our study is not to trigger an anthropological debate about the historical perception of the bride price. However, we consider current dynamics and their impact on women's lives in rural West-Africa. 
between bride price payments and the number of children, namely that women who receive a higher bride price have fewer children. Indeed, at the mean bride price, a woman reduces her number of children by 0.5. Thus, the more a woman is perceived as precious investment by her in-laws, the lower the pressure upon her for reproductive success. The results highlight the importance of the bride price in establishing a socially accepted and enforceable contract. The higher the man's investment in his wife, the higher her value and appreciation and consequently the fewer children she has to give birth to. This suggests that the bride price system influences the bargaining power and independence of women in a pervasive manner. We address the potential endogeneity issues related to the omitted variable bias or the measurement error of the bride price through a series of robustness tests. We demonstrate that our findings are not driven by these sources of bias, with our results even robust if we control for income, wealth and the economic conditions at the time of the marriage, or if we use alternative specification. We also carry out a very detailed analysis by exploring various transmission channels along which the marriage payments influence the fertility decisions.

The remainder of the paper is structured as follows. Section 2 reviews the existing literature. In Section 3 , we present the study context and the data.Section 4 introduces the empirical strategy and the main results. Endogeneity issues and robustness checks are discussed in Section 5. Heterogeneous effects and various transmission channels are presented in Section 6. Section 7 concludes and presents the implications of our results.

\section{Background on marriage payments}

Family and marriage dynamics were first put on the agenda of economic research by Becker (1981), whose model of marriage rests upon the equilibrium of a matching exercise, fitting men and women together as couples. This assortative mating model can explain the existence of dowries and bride price payments, with the latter particularly arising in polygamous societies where women are relatively scarce. These payments allow differentiating between single and divorced women, for example, with the former being more highly valued on the marriage market (Goldschmidt, 1974; Papps, 1980). Thus, Becker views the bride price payment 
as an investment. According to his analysis, bride price payments are forfeited if husbands divorce their wife without cause. This explains why husbands have the incentive to maintain the social contract in which they have engaged. In turn, wives have to repay their ex-husbands if they leave them without any reason.

Marriage payments are a common concept in almost all societies. Despite hardly ever being practiced in the Western world, they remain prominent in many developing countries (Andersson, 2007). To date, most of the studies concerning marriage payments have been carried out in South Asia. In this region, marriage payments are mostly found in the form of dowries, meaning that the marriage payment is given by the bride's parents to the groom. Several studies within the existing literature have analyzed the relationship between dowry payments and various other factors such as the surplus of women in the marriage market (Rao, 1993), the cast system (Anderson, 2003), domestic violence (Srinivasan and Bedi, 2007), female human capital endowment (Sharma and Frijters, 2009) and family planning (Peters, 2011). Botticini and Siow (2003) argue that dowries and bequests are used in patrilocal societies to avoid free-riding behavior between siblings, as well as efficiently transferring wealth from parents to children.

Most African countries base the marriage contract upon bride price payments rather than dowries $4^{4}$ A plethora of reasons for this difference in marriage systems has been discussed (Botticini and Siow, 2003). First, Africa is characterized by collective rights that prevent a dowry system from evolving, as the possibility for parents to transfer individual wealth to their children are limited. Second, Africa has a non-plough agricultural system where female labor is more important than in the plough agriculture that exists in Asia (Boserup, 1970). African agriculture rather destroys the land that is cultivated and moves on to new places for cultivation, thus limiting the possibilities to introduce dowries and bequests. Third, dowries are found in monogamous societies, whereas African societies have a polygamous structure (Bergstrom, 1994; Tertilt, 2005).

The economics of bride price systems has received increasing attention in recent years. For instance, it has been shown that higher bride price payments do not

\footnotetext{
${ }^{4}$ There are also cases in Asia where bride price payments are practiced, such as in Thailand (Cherlin and Chamratrithirong, 1988) or China, where it is possible to find the two systems of marriage payments coexisting (Anderson, 2007; Brown, 2009).
} 
influence the behavior of husbands towards their wives, whereas higher dowries do (Zhang and Chan, 1999). In a study using Ugandan data, Bishai and Grossbard (2010) interpret the bride price as the women's sexual fidelity to men, because this marriage payment is associated with a lower rate of extra-marital sexual relationships for women, yet not for men. In the specific case of Senegal, Gaspart and Platteau $(2010,2007)$ show that the value of the bride price is determined by a woman's socio-economic characteristics, as well as strategic behavior by herself and her parents. The bride and her altruistic parents can prefer a (relatively) low bride price in the case of a love marriage in order to reduce the risk of ill-treatment and the marriage's failure.

\section{Survey context and data}

\subsection{The survey}

Data are provided by a household survey carried out in eight regions of Senegal. $5^{5}$ The survey was part of the program evaluation of a rural electrification initiative by the UNDP known as a multifunctional platform. The dataset includes two waves: the baseline survey was carried out between May and July 2009 and the second survey between April and June 2011. Villages were randomly selected based on the criterion of not having access to energy. Within the villages, households were also selected at random from the list of resident households supplied by the head of the village. The sample is thus representative of rural Senegal in eight of 14 regions in which subsistence agriculture is the most prevalent form of income generation.

For the purpose of our analysis, we restrict the sample to individuals who were married at the moment of the survey and responded to the gender questionnaire. While the majority of these couples are the same across waves, not all couples were reinterviewed in 2011 as they might have been replaced by another couple living in the same household. Therefore, we also have new couples that enter the sample in 2011. Consequently, we establish an unbalanced panel of married

\footnotetext{
${ }^{5}$ The regions are Diourbel, Fatick, Kaolack, Kedougou, Kolda, Louga, Tambacounda and Thies.
} 
couples, which allows us to compare the dynamics of marriage payments across regions. We noticed among the same couples present in the two waves that the amount of the bride price recalled by the same woman differed from one survey round to the next. We use this variation to later address the potential recall bias.

\subsection{Descriptive statistics}

We present summary statistics in Table 1. The vast majority of the households (95\%) are Muslims and consider themselves as members of the Wolof (43\%), Pular $(24 \%)$ or Serere (18\%) ethnic group. Moreover, almost one-fifth of the households are casted and $42 \%$ of the couples report living in a polygamous union. In the case of polygamy, first wives represent $26 \%$ of our sample ${ }^{6} \mathrm{We}$ proxy for wealth with landownership, which represents the number of arable plots owned by the household. On average, households own 2.51 plots, indicating that they are in agriculture and derive their living from farming. In order to capture the economic conditions at the time of the marriage, we build five cohorts derived from the difference between the year of the survey and the year of marriage. For instance, the year of marriage cohort $[0,5[$ is an indicator variable equal to one if the marriage was celebrated less than five years before the survey, while the year of marriage cohort $[5,10[$ codes for women who were married between five and ten years before the survey. We construct the year of marriage cohorts [10, 15[, [15, $20[$ and $[25,$.$] by following the same logic. 42 \%$ of the marriages were celebrated at least 25 years before the survey.

At the level of the individual couple, we derive most information from the woman. Women have on average 5.20 children, including both those who are alive and those who have died. The average woman is almost 37 years old, which makes her 14 years younger than her husband. This gender age gap is not surprising in rural Senegal and gives an indication of the timing of marriages and the underlying decision process: Men first need to acquire the necessary assets to set up a family, of which the bride price paid at the wedding constitutes a non-negligible part.

\footnotetext{
${ }^{6}$ Concerning the ranking of the wives, being the first wife is coded as a dummy equal to one if the woman is the first wife and 0 otherwise. The same logic applies for the indicator variables second wife and third or fourth wife. The excluded category is constituted by monogamously married women.
} 
While the average bride price in the sample is FCFA 240,917 (367 Euros), there is considerable variation and the mean is driven by some large amounts, as the median of FCFA 75,000 (114 Euros) shows. Women marry young, as the average age at first marriage indicates: they are below 18 years on average. Moreover, divorce is rare (8\%). Women's position is weak, with only $16 \%$ knowing how to read and write, whereas $44 \%$ of their husbands are alphabetized. Nonetheless, almost $47 \%$ of the women in the sample are economically active beyond household chores and family farm work, while $91 \%$ of men pursue additional economic activities. Women's subordinate position is also demonstrated with respect to their living arrangements. Women typically live close to their in-laws, with the couples living on average only $2.55 \mathrm{~km}$ away from the husband's parents. By contrast, this distance is estimated at $20 \mathrm{~km}$ for the woman's parents. This last pair of descriptive statistics represents virilocality in the rural communities where wives have to take care of their parents in-law and the domestic activities in the in-laws home. Last but not least, these descriptive statistics also show that the majority of couples come from the same region, as indicated by the relatively short distances to the parents in general.

Overall, summary statistics leave no doubt that the sample at hand represents poor rural villages in Senegal, within which women are in a considerably weaker position than men in terms of education and (economic) empowerment.

\section{Econometric framework and main results}

\subsection{Empirical strategy}

The linear regression framework is employed to analyze the link between bride price payments and fertility decisions. We consider the following empirical model:

$$
y_{i h r t}=\beta_{0}+\beta_{1} \log (B P)_{i h r t}+\beta_{2} W_{i h r t}+\beta_{3} H_{i h r t}+\beta_{4} H H_{h r t}+\mu_{t}+\lambda_{r}+\epsilon_{i h r t},
$$

where the subscript $i$ denotes wife, $h$ household, $t$ year and $r$ region. The dependent variable $y_{i h r t}$ is the number of children a woman has given birth to at 
the moment of the survey. The variable of interest is the logarithm of the bride price $\log (B P)_{i h r t}$. We also control for the socio-demographic characteristics of the women $W_{i h r t}$ such as age and its square, the age of the women at her current marriage and its square, as well as a binary variable equal to one if the women is literate. The variable literacy is used to proxy for the education level. Similarly, we control for the husband's characteristics $H_{i h r t}$ such as his age and its square, as well as a binary variable equal to one if he is literate. In addition, we take into account household characteristics $H H_{h r}$ by controlling for ethnicity, religion and caste as well as the type of marriage practiced. The marriage form is captured by an indicator variable coding for polygamous unions. Controlling for wife-, husband- and household-specific characteristics allows us to address issues of omitted variable bias at the level of the individual couple. In addition, we include year of survey dummies $\mu_{t}$ in our basic regression model to capture time-specific effects.

Regional heterogeneity is taken into account by including regional fixed effects $\lambda_{r}$ in equation (1). By doing so, we can rule out sources of bias stemming from regional characteristics that are common across couples residing in a particular region. Finally, the unexplained residual is captured by $\epsilon_{i h r t}$. Standard errors are clustered at the regional level to account for intra-cluster correlations.

In the empirical analysis, we will demonstrate the robustness of our results by controlling for other sources of endogeneity. Furthermore, we will control for different sources of heterogeneity, which will also shed light on transmission channels.

\subsection{Main results}

The results clearly show that the bride price is negatively related to the number of children. Whenever the groom gives a higher bride price, he demonstrates his willingness to treat his wife well and avoid the risk of divorce, which would correspond with a financial failure of his investment. In consequence, a husband who has paid a higher bride price gives greater independence to his wife by reducing the pressure on her to produce offspring. In turn, this increases the wife's bargaining power in the relationship and the household, as she is more valued as a person.

We start the analysis by comparing plain vanilla OLS results with results account- 
ing for regional heterogeneity. Table 2 presents the results. Controlling for wife and husband characteristics jointly, we find a significant and negative relationship between the bride price and the number of children. In Column 1 of Table 2, the OLS framework yields a significant and negative coefficient associated with the log bride price payment. Controlling for polygamy, ethnicity, religion and caste in the OLS specification (Column 2 of Table 2 renders the coefficient associated with bride price insignificant ( $p$ - value of 14.8\%). However, the coefficient remains significant at the $5 \%$ level when employing regional fixed effects (Column 3 and 4 of Table 2). Nonetheless, it drops in size, indicating that socio-cultural and traditional factors such as ethnicity, religion and caste are important determinants of fertility (Column 4 of Table 2). At the mean bride price, the number of children a woman gives birth to is reduced by 0.5 . At the median bride price, a women has 0.45 children less on average. Put differently, every other women who receives a bride price between the median and the mean value of our sample gives birth to one child less. Given that this is an ex post analysis relying on observed fertility outcomes, we control for the age of the husband and wife, as well as their age at marriage. Unsurprisingly, older women have given birth to more children, although this relationship is non-linear. The turning point is at the age of 50, which corresponds to the average age of natural menopause according to medical research. At the same time, we observe that the younger a bride at her marriage, the more children she has given birth to at the date of the survey. However, the relationship between the age at marriage and the fertility decisions is U-shaped, with 34 years marking the threshold. Similarly, literacy has the expected negative sign, suggesting that more educated women tend to have fewer children. Nonetheless, the significance of the coefficient associated with literacy vanishes once we control for regional fixed effects. This can be explained by the fact that within the sample at hand, the education level across women is low, resulting in little variation across women (Columns 3 and 4 of Table 2).

While we do not find any significant differences in fertility patterns across religious groups or castes, the ethnic group of the Serere tend to have one more child on average. This result has also been found in the Demographic and Health Surveys and confirms the representativeness of our dataset for rural Senegal.

Taken together, the impact of the covariates on fertility decisions emphasizes the 
contextual dimension of both marriage arrangements and ensuing family planning ${ }^{7}$ The analysis demonstrates that the individual characteristics of husband and wife shapes fertility decisions, as does the timing of their marriage. In what follows, we test the robustness of our results by considering income, wealth and economic conditions, as well as using some alternative specification. We also explore the extent to which the couple's characteristics are linked to bride price payments. By conducting a differential analysis, we detect transmission channels for the bride price and improve our understanding of the institutional settings of the marriage market in rural Senegal. ${ }^{8}$

\section{$5 \quad$ Dealing with endogeneity}

In our econometric approach, we use the detailed information provided by the household survey and control for the characteristics of the couple and the household. We also rule out sources of biases that possibly originate from time-invariant regional characteristics and common trends through the region and survey year fixed effects, respectively. Despite paying attention to all these elements, we might still face endogeneity problems due to the omission of relevant variables such as income and wealth. At the same time, income and wealth themselves are considered endogenous. However, even if these variables tend be endogenous, by not controlling for them we might introduce omitted variable bias. Therefore, it is useful to compare our results with and without income variables. At the very least, this allows us to ascertain whether our findings are robust to their inclusion. Moreover, we have information about the landownership status of the household, which serves as a measure of wealth. Given that this variable is a good proxy for permanent income and can be considered exogenous due to the lack of active land markets, we also include it in our regressions. Moreover, we also consider the economic conditions at the time of the marriage by including year of marriage cohort

\footnotetext{
${ }^{7}$ The results are robust for simple clustering and multi-way clustered standard errors. The latter option allows us to account for the small number of clusters (Cameron et al., 2011).

${ }^{8}$ Given that our dependent variable, number of children, is a count variable, it might be argued that the Poisson model is more suited for the analysis. We also employed the Poisson model and derived qualitatively similar results. These findings are not presented for the sake of brevity.
} 
effects. These marriage cohort dummies control for two sources of bias. First, they allow us to address the possible omitted variable bias concerning economic conditions at the time of the marriage. At the same time, they address the second source of endogeneity introduced by the measurement error in the amount of the bride price due to the recall nature of the data. As with all analyses that employ recall data, we face the challenge that human memories are adaptive. Therefore, it is likely that the precise amount of the bride price is not correctly expressed by the women interviewed, with variations possibly emerging due to the duration between the year of the survey and the year of the marriage. One way of capturing this effect is to control for the year of marriage. Finally, in order to ensure that the measurement error does not affect the robustness of our results, we use an alternative specification that considers the log of the mean bride price between 2009 and 2011 reported by each woman who was interviewed twice.

\subsection{Controlling for income and wealth}

In order to disentangle the income effect from the bride price, we separately include income generating activities (IGA) undertaken by the wife and husband in our empirical specification. The variable is binary and equal to one if the wife (the husband) is economically active. By including IGAs, we control for the labor market participation of women and men, which can influence both the amount of the bride price and the number of children. We observe that the wife's income generating activities increase her number of off-spring, while such activities by the husband have no impact on fertility decisions (Column 1 of Table 3). This result demonstrates that women provide most of the resources for raising their children themselves, with paternal contributions being limited (Desai, 1992).

We have not yet accounted for wealth in the analysis, although assets and wealth clearly influence both bride price payments and fertility decisions. Therefore, we include landownership as a control variable in the next specifications. This is considered a suitable wealth indicator as inheritance is patrilineal in rural Senegal and no active land markets exist.9 In Column 2 of Table 3, we control for the

\footnotetext{
${ }^{9}$ Our dataset also contains information about women who bring land into the marriage. However, given that this group of women represents less than $4 \%$ of the sample, the variation in female landownership is too small to be relevant for differences in personal wealth and thus we
} 
IGAs of the wife and her husband jointly with landownership, while in Column 3 we consider landownership as the only wealth indicator. Despite controlling for wealth, socio-cultural factors and regional heterogeneity, the negative relationship between bride price payments and the number of children a woman gives birth to remains. The wealth effect is non-negligible and is represented by the positive impact of landownership on the number of offspring.

\subsection{Controlling for the economic conditions at the time of the marriage}

Economic conditions at the time of the marriage are considered underlying factors that can influence both the amount of the bride price and the ensuing number of children. In order to deal with this source of omitted variable bias, we include year of marriage cohort fixed effects in our empirical specification, which allows us to take into account economic variables such as the level of prices or inflation rates, as well as positive or negative shocks such as weather events that prevailed around the wedding period. By employing five year windows, we rule out any impact of the economic context at the beginning of the marriage on both the bride price negotiations and the initial fertility decisions.

Moreover, as previously mentioned, the year of marriage cohort fixed effects also address the measurement error of the bride price payment by capturing the effect of time on the memories of the women interviewed. Column 4 of Table 3 shows the results with year of marriage cohort fixed effects. While the coefficient associated with bride price remains significant and negative, its magnitude is slightly lower compared to Column 3 of Table 2, indicating that the overall economic conditions around the wedding play a role in ensuing fertility decisions.

\subsection{Alternative specification}

Although we control for the economic conditions at the time of the marriage, we want to ensure that the measurement error resulting from the recall of the bride price does not invalidate our results. We note that the average bride price in exclude this variable from the empirical analysis. 
2009 was different from that in 2011, on average by FCFA 128,106.9 (195 Euro), which is significant at the $1 \%$ level (Table 4). The mean bride price between these years is evaluated on average at FCFA 263,343.3 (401 Euro). Consequently, we implement an alternative specification that uses the log of the mean bride price between 2009 and 2011 rather than the actually reported values in every year. In Columns 1 to 4 of Table 5, we run the same estimations as in Table2, Region fixed effects results are similar in terms of significance and sign, and the results remain unchanged even when we control for landownership and year of marriage cohorts (Column 5 of Table 5): The relationship between bride price and the number of children remains significant and negative. The only difference between the main results and those using the mean bride price is the size of the coefficients, whose magnitude is higher in absolute terms when we use the mean bride price rather than the initial values. Consequently, we prefer to be conservative in assessing the magnitudes and thus focus on those in Table 2, which are lower in absolute terms. Given that these various robustness checks show that our results are not driven by an omitted variable or a measurement error bias, we proceed further in our analysis by exploring possible transmission channels that can explain the negative relationship between the bride price and fertility decisions.

\section{Heterogeneous effects and transmission chan- nels}

To gain a more precise picture of the differential impact of bride price payments with respect to human capital and wealth, we try to carve out potential transmission channels along which these nuptial payments affect fertility decisions. Therefore, we introduce various interaction terms between the bride price and human capital, as well as wealth and income. 


\subsection{Heterogeneity with respect to human capital and in- come}

First, we begin with the literacy of the wife. In Column 1 of Table 6, we compare the coefficient estimates associated with the differential bride price for educated versus uneducated women, whereby it turns out that they are identical ( $p-$ value of the $F$-test $46 \%$ ). While this gives the initial impression that higher bride price payments reduce the reproductive pressure for uneducated women, the coefficient estimates for educated versus uneducated women are statistically identical. Nonetheless, women who are economically dependent on their husband and received a low bride price tend to have more children, suggesting that they are less valued and have to gain respect through reproductive success (Column 2 of Table 6).

For men, the human capital and income dynamics with respect to bride price are the opposite of those for women. Educated men and those with income generating activities expect their wives to have fewer children when a high bride price has been paid (Columns 3 and 4 of Table 6). However, only the educational difference is statistically significant ( $p$-value of the $F$-test $2 \%$ ).

These findings indicate that poor women and men with low levels of education are the most negatively affected by the tradition of bride price payments. Poor women have little bargaining power to ask for high bride price payments, which limits them in their choice of a husband and might result in less affectionate yet rather affordable marriage arrangements. Furthermore, being in such a marriage of convenience puts them under high reproductive pressure.

\subsection{Heterogeneity with respect to economic conditions and wealth}

Wealth and economic conditions during the period of the wedding lend themselves as further possible transmission channels. For households that own land, there is a negative relationship between the bride price payments and fertility decisions (Column 1 of Table 7). By contrast, this effect does not exist for households without land ( $p$-value of the $F$-test $8 \%$ ). Hence, women who received a high bride 
price are valued per se in relatively wealthier households, facing less pressure for reproductive success and more (economic) independence. In the agrarian society of rural Senegal, where wealth is determined by the land owned, relatively richer husbands can afford higher bride prices while putting their wives under less pressure for offspring. Given that these men derive part of their reputation from their wealth, their prestige depends less on having a large family. However, this is not to suggest that landowners who can afford the market bride price have no children at all, rather that they merely have fewer children.

Have bride price dynamics changed over time? The coefficients of the interaction terms between the different year of marriage cohorts and the bride price are not significant (Column 2 of Table 7). Thus, women are equally valued independent of the marriage cohort to which they belong. These results demonstrate that the effect of bride price payments on fertility decisions is stable over time, which reinforces the robustness of our findings.

\subsection{Appreciation of the bride by the husband}

In this part, we explore the bride's appreciation by the husband and her reputation as other possible channels that explain variations in the bride price and the negative relationship between bride price payments and the number of children. To this end, we consider the age at marriage, love versus arranged marriages and divorce.

\section{Age at marriage}

We first consider the woman's age at the time of the marriage, splitting the sample into brides below and above 20 years of age at the point of their marriage (Column 1 of Table 8). At first glance, the results suggest that higher bride price payments for older women reduce their pressure for offspring more than for younger women. However, the $F$-test of $16 \%$ reveals that we cannot conclude the age of the wife at marriage to be considered a transmission channel. The dynamics and expectations linked to the bride price are similar for women who get married young (below the age of 20) and old (above the age of 20).

\section{Love versus arranged marriage}

Bride price dynamics can be further nuanced by analyzing the nature of the marriage, namely love versus arranged marriage. While we cannot control for love, 
we have information about the age distance between husband and wife. By controlling for the age distance of the couple, we build on anthropological evidence that arranged marriages between young girls and older men are not uncommon in rural Senegal (Foley and Drame, 2012). In Column 2 of Table 8, we present the results controlling for age distance and its interaction with the bride price payment, finding a direct effect of age distance: the larger the distance, the more pressure the woman has to give birth. However, there is a threshold at which a higher age distance reduces the number of children, marked by when the age gap exceeds 23 years.

In addition, we interact the bride price payments with a dummy equal to one if the age distance is greater than 10 years. The interaction term further reinforces the finding that higher bride prices reduce the number of children that a women has to give birth to in arranged marriages. The interaction between bride price payments and (almost) no age distance proxies for a love marriage, indicating that individuals of the same age have a higher likelihood of finding each other and getting married due to their mutual affection. Bride price payments are not needed to regulate fertility decisions in such love marriages, whereas for arranged marriages in which a considerably older husband has chosen a young girl, the amount of the bride price payment is decisive for the woman's pressure for offspring ( $p-$ value of the $F$-test $6 \%$ ). This finding is in line with Gaspart and Platteau $(2010,2007)$ as it shows that bride price payments are less important for love marriages. In a love relationship, the amount of the bride price loses its power over future family decisions taken by the couple. However, the bride price is a powerful tool in an arranged marriage (large age distance). In such cases, if the bride and her family can negotiate a substantial payment, she will face less pressure for reproductive success.

\section{Divorce}

We further explore the situation of divorced women and it appears that being a divorced woman has no direct effect on fertility decisions (Column 3 of Table 8). However, these women only represent a small share of the sample (8\%) and therefore the dataset exhibits little variation across women concerning their status prior to the current marriage. When turning to the differential effect of the bride price that applies for divorced women, we observe no difference in fertility decisions 
for women who are married for the first time versus women who had a divorce prior to the current marriage ( $p$-value of the $F$-test $22 \%$ ). Thus, divorce is not a transmission channel through which the bride price affects fertility decisions.

\subsection{Household context}

We complete our analysis by identifying transmission channels at the household level such as household organization, the wife's rank and the distance to both the wife's and husband's parents.

\section{Polygamous versus monogamous households}

Being in a polygamous household increases the number of children that a woman gives birth to (Column 1 of Table 9). This can be explained by the competition between wives, particularly with respect to inheritance. The higher the number of children of any individual wife, the higher the share that she and her children will inherit following the husband's death. However, once we jointly control for the rank of the wife within the household, the positive and significant coefficient estimate associate with being in a polygamous union fades away. Again, competition is at place, with co-wives competing for the husband's attention, as well as resources.

The competition hypothesis is reinforced when we split the sample between polygamous and monogamous households. For women living in a polygamous household, a lower bride price payment increases fertility pressure, while the bride price payment has no effect on the couple's decisions concerning fertility in a monogamous household ( $p$-value of the $F$-test $2 \%$ ).

This finding also indirectly supports the results about love versus arranged marriages: whenever a couple is closer in terms of affection, marriage payments have no significance and thus do not influence fertility decisions. In turn, if a woman is just an addition, her value and appreciation is defined by the bride price payment. We further find that once a woman enters a polygamous household, her rank within the household neither directly nor indirectly influences her number of children (Column 2 of Table 9).

\section{Distance to parents}

We also explore the distance to the parents of the wife and the husband. While the 
first variable has no effect on the fertility decisions of the couple, we find a positive association between the number of children and the distance to her in-laws. Put differently, women who live near their in-laws have higher reproductive pressure. However, the magnitude of the coefficient is close to 0 and, despite being precisely estimated, the coefficient has no economic significance (Column 3 of Table 9). We subsequently split the sample between women living more than 20 kilometers from their parents and those who live within a radius of $20 \mathrm{~km}$ from their parents, finding no differential effects with respect to the impact of bride price payments on fertility decisions ( $p$-value of the $F$-test 19\%). However, when we compare women living far from their parents in-law, namely those for whose residence is located at least 20 kilometers away, to those who live closer, bride price dynamics with respect to distance appear. In response to high bride price payments, women close to their parents in-law reduce the number of children considerably more compared to those who live far away from their in-laws ( $p$-value of the $F$-test $4 \%$ ). In other words, fertility pressure is stronger for women who receive a low bride price and live close to their in-laws compared to those who live far from their parents in-law. When women live close to their in-laws, they are pressured by the family and judged according to the number of children they give birth to. Living further away from the in-laws implies a higher level of (economic) independence and concomitantly less fertility pressure.

\section{Conclusion and Implications}

Our results suggest that the bride price system has considerable implications for women's bargaining power and independence. A woman's say in a relationship is determined by a payment between the groom's and bride's families. If the payment is high, the likelihood of reproductive pressure will be lower. If the payment is low -and cash constraints in rural Senegal are likely to limit the leeway and thus choices for young men- the women who are chosen might not be the preferred ones and fertility pressure increases. Moreover, this system brings about inequalities in the socio-economic conditions of women, depending on the amount of payment they received upon their marriage.

A marriage represents a social contract between a man and a woman, including 
their respective families. This contract can be viewed as insurance in the context of rural Senegal, whereby both parties have an incentive to keep to it. The roles of the partners are clearly defined. The husband takes the woman and gives her economic security. His appreciation of the bride and the value she represents for him is expressed by the bride price he pays. Whenever the groom is willing to give a higher bride price, he demonstrates his willingness to treat his wife well and avoid the risk of divorce, which would correspond with a financial failure of the investment. In turn, from the bride price payment received, the women can judge whether she needs to gain reputation within the groom's family by giving birth to many children. This simple contract is socially accepted and so strong that it needs no enforcement mechanisms beyond the local community in which it is embedded. In fact, the more the husband appreciates his wife, as demonstrated by the bride price payment, the less he expects her to prove herself through reproductive success. Furthermore our findings also imply that a low bride price increases the pressure for women to gain reputation through a large number of children.

While this type of marriage contract seems odd to Western observers, this mutual insurance is prominent in poor rural societies, covering not only the spouses but also their families. Therefore, efforts to eradicate the tradition of bride price payments and formalize marriages according to national legal standards might especially make the women concerned worse off. Women in these poor societies tend to have lower levels of education than men, as well as less access to information, which prevents them from seeking (legal) support. Moreover, as the traditional marriage system reinforces socio-economic differences, bride price payments cannot be viewed as a means of empowering women; rather, they keep them dependent. However, bride price payments already have less power over women who are economically independent at present. Consequently, a direct change of the bride price system might be too challenging a task, although economic empowerment will give leeway to girls, even in traditional societies. The established marriage contract can only be broken indirectly by giving women more possibilities for economic independence.

Bride price payments are not only an African phenomenon, having also gained increasing importance in China in recent years, while marriage migration for high bride prices is common (Davin 2005). However, even in China, where bride price 
payments have exploded in value, adverse effects have been documented for the migrating women and for men from poor areas. Thus, bride prices are an important marriage market institution that remains in existence even as countries and regions develop. However, the identified transmission channels that foster the continuance of this tradition can be used to counteract. One possible entry point is family planning programs. On the one hand, our findings suggest that these programs might be inefficient if they do not take into account norms and values that define women's behavior with regard to fertility decisions in traditional societies. At the same time, these programs can be used to educate women. Moreover, family planning programs that are integrated in broader support structures can offer women opportunities to increase their (economic) independence such that the social contract that stipulates the marriage arrangements represents a tool of empowerment for young couples.

\section{References}

Anderson, Siwan. 2003. Why Dowry Payments Declined with Modernization in Europe but Are Rising in India. Journal of Political Economy, 111(2), 269310.

Anderson, Siwan. 2007. The Economics of Dowry and Brideprice. Journal of Economic Perspectives, 21(4), 151-174.

Becker, G.S. 1981. A Treatise on the Family. Harvard University Press.

Beegle, Kathleen, Frankenberg, Elizabeth, \& Thomas, Duncan. 2001. Bargaining Power Within Couples and Use of Prenatal and Delivery Care in Indonesia. Studies in Family Planning, 32(2), 130-146.

Bergstrom, Ted. 1994. On the Economics of Polygyny.

Bishai, David, \& Grossbard, Shoshana. 2007. Far Above Rubies: The Association Between Bride Price and Extramarital Sexual Relations in Uganda. IZA Discussion Papers 2982. Institute for the Study of Labor (IZA). 
Boserup, E. 1970. Woman's Role in Economic Development. George Allen and Unwin Limited.

Botticini, Maristella, \& Siow, Aloysius. 2003. Why Dowries? American Economic Review, 93(4), 1385-1398.

Brown, Philip H. 2009. Dowry and Intrahousehold Bargaining: Evidence from China. Journal of Human Resources, 44(1).

Cameron, A. Colin, Gelbach, Jonah B., \& Miller, Douglas L. 2011. Robust Inference With Multiway Clustering. Journal of Business 83 Economic Statistics, $\mathbf{2 9}(2), 238-249$.

Cherlin, Andrew, \& Chamratrithirong, Aphichat. 1988. Variations in Marriage Patterns in Central Thailand. Demography, 25(3), 337-353.

Davin, Delia. 2005. Marriage Migration in China: The Enlargement of Marriage Markets in the Era of Market Reforms. Indian Journal of Gender Studies, 12(2-3), 173-188.

Desai, Sonalde. 1992. Children at Risk: The Role of Family Structure in Latin America and West Africa. The Population and Development Review, 689-717.

Foley, Ellen E., \& Drame, Fatou Maria. 2013. Mbaraan and the Shifting Political Economy of Sex in Urban Senegal. Culture, Health 83 Sexuality, 15(2), 121134. PMID: 23181265.

Gaspart, Frederic, \& Platteau, Jean-Philippe. 2010. Strategic Behavior and Marriage Payments: Theory and Evidence from Senegal. Economic Development and Cultural Change, 59(1), 149-185.

Goldschmidt, Walter. 1974. The Economics of Bride Price Among the Sebei and in East Africa. Ethnology, 13(3), 313-331.

Kanji, S.S.M., \& Camara, F.K. 2000. L'union matrimoniale dans la tradition des peuples noirs. Logiques juridiques. Harmattan. 
Papps, I. 1980. For Love or Money?: A Preliminary Analysis of the Economics of Marriage and the Family. Hobart paper. Institute of Economic Affairs.

Peters, Christina. 2011. Effects of Family Planning and Health Services on Women's Welfare: Evidence on Dowries and Intra-Household Bargaining in Bangladesh. Review of Economics of the Household, 9(3), 327-348.

Platteau, Jean-Philippe, \& Gaspart, Frederic. 2007. The Perverse Effects of High Brideprices. World Development, 35(7), 1221-1236.

Rao, Vijayendra. 1993. The Rising Price of Husbands: A Hedonic Analysis of Dowry Increases in Rural India. Journal of Political Economy, 101(4), 66677.

Sharma, Amarendra, \& Frijters, Paul. 2009. Groom Price - Female Human Capital: Some Empirical Evidence. The Journal of Socio-Economics, 38(2), 270279 .

Srinivasan, Sharada, \& Bedi, Arjun S. 2007. Domestic Violence and Dowry: Evidence from a South Indian Village. World Development, 35(5), 857-880.

Tertilt, Michele. 2005. Polygyny, Fertility, and Savings. Journal of Political Economy, 113(6), 1341-1370.

Zhang, Junsen, \& Chan, William. 1999. Dowry and Wife's Welfare: A Theoretical and Empirical Analysis. Journal of Political Economy, 107(4), 786-808. 
Table 1: Descriptive statistics

\begin{tabular}{|c|c|c|}
\hline & Mean & Std. Dev. \\
\hline Number of children & 5.20 & 3.10 \\
\hline Bride price & $240,917.5$ & $340,149.2$ \\
\hline \multicolumn{3}{|l|}{ Characteristics of the wife } \\
\hline$\overline{\text { Age }}$ & 37.00 & 12.18 \\
\hline Age at marriage & 17.85 & 4.63 \\
\hline Literacy & 0.16 & 0.37 \\
\hline Income generating activity & 0.47 & 0.5 \\
\hline Divorce & 0.08 & 0.27 \\
\hline \multicolumn{3}{|c|}{ Rank of the wife in polygamous household } \\
\hline First wife & 0.26 & 0.44 \\
\hline Second wife & 0.13 & 0.34 \\
\hline Third or fourth wife & 0.02 & 0.15 \\
\hline \multicolumn{3}{|l|}{ Characteristics of the husband } \\
\hline$\overline{\text { Age }}$ & 51.03 & 14.33 \\
\hline Age distance & 14.89 & 10.61 \\
\hline Literacy & 0.44 & 0.50 \\
\hline Income generating activity & 0.91 & 0.29 \\
\hline \multicolumn{3}{|l|}{ Household characteristics } \\
\hline$\overline{\text { Polygamous }}$ & 0.42 & 0.49 \\
\hline Distance to wife's parents & 20.00 & 62.12 \\
\hline Distance to husband's parents & 2.55 & 29.17 \\
\hline \multicolumn{3}{|l|}{ Ethnicity } \\
\hline Pular & 0.24 & 0.43 \\
\hline Serere & 0.18 & 0.38 \\
\hline Manding & 0.06 & 0.23 \\
\hline Soninké & 0.04 & 0.21 \\
\hline Diola & 0.02 & 0.15 \\
\hline Other ethnicity & 0.03 & 0.17 \\
\hline \multicolumn{3}{|l|}{ Religion } \\
\hline Christian & 0.04 & 0.19 \\
\hline Other religion & 0.01 & 0.10 \\
\hline Caste & 0.18 & 0.39 \\
\hline Landownership & 2.51 & 1.73 \\
\hline \multicolumn{3}{|l|}{ Year of marriage cohort } \\
\hline Year of marriage cohort $[0,5[$ & 0.13 & 0.34 \\
\hline Year of marriage cohort $[5,10[$ & 0.16 & 0.37 \\
\hline Year of marriage cohort $[10,15[$ & 0.15 & 0.35 \\
\hline Year of marriage cohort $[15,20[$ & 0.14 & 0.35 \\
\hline Observations $2 ?$ & \multicolumn{2}{|c|}{2,241} \\
\hline
\end{tabular}

Notes:The reference group for the variable rank of the wife in polygamous household is monogamously married women. The reference group for the variable ethnicity is Wolof. The reference group for the variable religion is Muslim. The reference group for the year of marriage cohorts is the cohort $[25,$.$] .$ 
Table 2: Bride price and fertility: Main results

\begin{tabular}{|c|c|c|c|c|}
\hline & $(1)$ & $(2)$ & $(3)$ & $(4)$ \\
\hline Bride price $(\log )$ & $\begin{array}{c}-0.048^{*} \\
(0.028)\end{array}$ & $\begin{array}{c}-0.041 \\
(0.028)\end{array}$ & $\begin{array}{c}-0.048^{* *} \\
(0.015)\end{array}$ & $\begin{array}{c}-0.040^{* *} \\
(0.013)\end{array}$ \\
\hline \multicolumn{5}{|l|}{ Characteristics of the wife } \\
\hline$\overline{\text { Age }}$ & $\begin{array}{c}0.500^{* * *} \\
(0.026)\end{array}$ & $\begin{array}{c}0.511^{* * *} \\
(0.026)\end{array}$ & $\begin{array}{c}0.498^{* * *} \\
(0.044)\end{array}$ & $\begin{array}{c}0.508^{* * *} \\
(0.042)\end{array}$ \\
\hline Age square & $\begin{array}{c}-0.005^{* * *} \\
(0.000)\end{array}$ & $\begin{array}{c}-0.005^{* * *} \\
(0.000)\end{array}$ & $\begin{array}{c}-0.005^{* * *} \\
(0.001)\end{array}$ & $\begin{array}{c}-0.005^{* * *} \\
(0.000)\end{array}$ \\
\hline Age at marriage & $\begin{array}{c}-0.209^{* * *} \\
(0.060)\end{array}$ & $\begin{array}{c}-0.259^{* * *} \\
(0.064)\end{array}$ & $\begin{array}{c}-0.229^{* *} \\
(0.077)\end{array}$ & $\begin{array}{c}-0.281^{* * *} \\
(0.063)\end{array}$ \\
\hline Age at marriage square & $\begin{array}{c}0.003^{* *} \\
(0.001)\end{array}$ & $\begin{array}{c}0.004^{* * *} \\
(0.001)\end{array}$ & $\begin{array}{l}0.003^{*} \\
(0.002)\end{array}$ & $\begin{array}{c}0.004^{* *} \\
(0.001)\end{array}$ \\
\hline Literacy & $\begin{array}{c}-0.274^{*} \\
(0.147)\end{array}$ & $\begin{array}{c}-0.325^{* *} \\
(0.145)\end{array}$ & $\begin{array}{l}-0.228 \\
(0.159)\end{array}$ & $\begin{array}{c}-0.277 \\
(0.166)\end{array}$ \\
\hline \multicolumn{5}{|l|}{ Characteristics of the husband } \\
\hline$\overline{\text { Age }}$ & $\begin{array}{c}0.052^{*} \\
(0.029)\end{array}$ & $\begin{array}{c}0.047 \\
(0.029)\end{array}$ & $\begin{array}{l}0.052^{*} \\
(0.027)\end{array}$ & $\begin{array}{c}0.043 \\
(0.026)\end{array}$ \\
\hline Age square & $\begin{array}{c}-0.000^{*} \\
(0.000)\end{array}$ & $\begin{array}{l}-0.000 \\
(0.000)\end{array}$ & $\begin{array}{c}-0.000^{*} \\
(0.000)\end{array}$ & $\begin{array}{l}-0.000 \\
(0.000)\end{array}$ \\
\hline Literacy & $\begin{array}{c}0.094 \\
(0.110)\end{array}$ & $\begin{array}{l}0.183^{*} \\
(0.111)\end{array}$ & $\begin{array}{c}0.048 \\
(0.226)\end{array}$ & $\begin{array}{c}0.104 \\
(0.226)\end{array}$ \\
\hline \multicolumn{5}{|l|}{ Household characteristics } \\
\hline $\begin{array}{l}\text { Polygamous } \\
\end{array}$ & & $\begin{array}{c}-0.081 \\
(0.120)\end{array}$ & & $\begin{array}{c}-0.119 \\
(0.142) \\
\end{array}$ \\
\hline Observations & 2,241 & 2,241 & 2,241 & 2,241 \\
\hline Region dummies & No & No & Yes & Yes \\
\hline Survey year dummies & Yes & Yes & Yes & Yes \\
\hline Ethnicity, religion and caste & No & Yes & No & Yes \\
\hline
\end{tabular}

Notes: All regressions include a constant. Robust standard errors are in parenthesis. Standard errors are clustered at the region level in Columns 3 and $4 .{ }^{* * *},{ }^{* *},{ }^{*}$ indicate significance at the $1,5,10 \%$ level, respectively. 
Table 3: Robustness checks: Controlling for income, wealth and economic conditions at the time of the marriage

\begin{tabular}{|c|c|c|c|c|}
\hline & $(1)$ & $(2)$ & $(3)$ & $(4)$ \\
\hline Bride price (log) & $\begin{array}{c}-0.036^{* *} \\
(0.014)\end{array}$ & $\begin{array}{c}-0.034^{*} \\
(0.014)\end{array}$ & $\begin{array}{c}-0.039 * * \\
(0.014)\end{array}$ & $\begin{array}{c}-0.036^{* *} \\
(0.014)\end{array}$ \\
\hline \multicolumn{5}{|l|}{ Characteristics of the wife } \\
\hline$\overline{\text { Age }}$ & $\begin{array}{c}0.499^{* * *} \\
(0.040)\end{array}$ & $\begin{array}{c}0.497^{* * *} \\
(0.039)\end{array}$ & $\begin{array}{c}0.506^{* * *} \\
(0.041)\end{array}$ & $\begin{array}{c}0.443^{* * *} \\
(0.073)\end{array}$ \\
\hline Age square & $\begin{array}{c}-0.005^{* * *} \\
(0.000)\end{array}$ & $\begin{array}{c}-0.005^{* * *} \\
(0.000)\end{array}$ & $\begin{array}{c}-0.005^{* * *} \\
(0.000)\end{array}$ & $\begin{array}{c}-0.004^{* * *} \\
(0.001)\end{array}$ \\
\hline Age at marriage & $\begin{array}{c}-0.277^{* * *} \\
(0.061)\end{array}$ & $\begin{array}{c}-0.280 * * * \\
(0.061)\end{array}$ & $\begin{array}{c}-0.284^{* * *} \\
(0.063)\end{array}$ & $\begin{array}{c}-0.263^{* *} \\
(0.082)\end{array}$ \\
\hline Age at marriage square & $\begin{array}{c}0.004^{* *} \\
(0.001)\end{array}$ & $\begin{array}{c}0.004^{* *} \\
(0.001)\end{array}$ & $\begin{array}{c}0.004^{* *} \\
(0.001)\end{array}$ & $\begin{array}{c}0.004^{* *} \\
(0.001)\end{array}$ \\
\hline Literacy & $\begin{array}{l}-0.297 \\
(0.162)\end{array}$ & $\begin{array}{l}-0.306 \\
(0.163)\end{array}$ & $\begin{array}{l}-0.286 \\
(0.166)\end{array}$ & $\begin{array}{l}-0.279 \\
(0.172)\end{array}$ \\
\hline Income gen. Activity (IGA) & $\begin{array}{c}0.243^{* *} \\
(0.087)\end{array}$ & $\begin{array}{c}0.241^{* *} \\
(0.086)\end{array}$ & & \\
\hline \multicolumn{5}{|l|}{ Characteristics of the husband } \\
\hline$\overline{\text { Age }}$ & $\begin{array}{c}0.045 \\
(0.025)\end{array}$ & $\begin{array}{c}0.050^{*} \\
(0.024)\end{array}$ & $\begin{array}{c}0.048 \\
(0.026)\end{array}$ & $\begin{array}{c}0.045 \\
(0.028)\end{array}$ \\
\hline Age square & $\begin{array}{l}-0.000 \\
(0.000)\end{array}$ & $\begin{array}{c}-0.000^{*} \\
(0.000)\end{array}$ & $\begin{array}{l}-0.000 \\
(0.000)\end{array}$ & $\begin{array}{l}-0.000 \\
(0.000)\end{array}$ \\
\hline Literacy & $\begin{array}{c}0.099 \\
(0.225)\end{array}$ & $\begin{array}{c}0.104 \\
(0.214)\end{array}$ & $\begin{array}{c}0.109 \\
(0.215)\end{array}$ & $\begin{array}{c}0.100 \\
(0.219)\end{array}$ \\
\hline Income gen. Activity (IGA) & $\begin{array}{c}0.063 \\
(0.107)\end{array}$ & $\begin{array}{c}0.029 \\
(0.111)\end{array}$ & & \\
\hline \multicolumn{5}{|l|}{ Household characteristics } \\
\hline Polygamous & $\begin{array}{l}-0.130 \\
(0.146)\end{array}$ & $\begin{array}{l}-0.148 \\
(0.152)\end{array}$ & $\begin{array}{c}-0.139 \\
(0.148)\end{array}$ & $\begin{array}{c}-0.141 \\
(0.148)\end{array}$ \\
\hline Landownership & & $\begin{array}{c}0.113^{* *} \\
(0.031)\end{array}$ & $\begin{array}{c}0.114^{* * *} \\
(0.029)\end{array}$ & $\begin{array}{c}0.114^{* * *} \\
(0.027)\end{array}$ \\
\hline Observations & 2,241 & 2,241 & 2,241 & 2,241 \\
\hline Region and survey year dummies & Yes & Yes & Yes & Yes \\
\hline Year of marriage cohort dummies & No & No & No & Yes \\
\hline
\end{tabular}

All regressions include a constant and controls for religion, ethnicity and caste. Robust standard errors are in parenthesis. Standard errors are clustered at the region level. ${ }^{* * *},{ }^{* *},{ }^{*}$ indicate significance at 1, 5, 10\% level, respectively. 


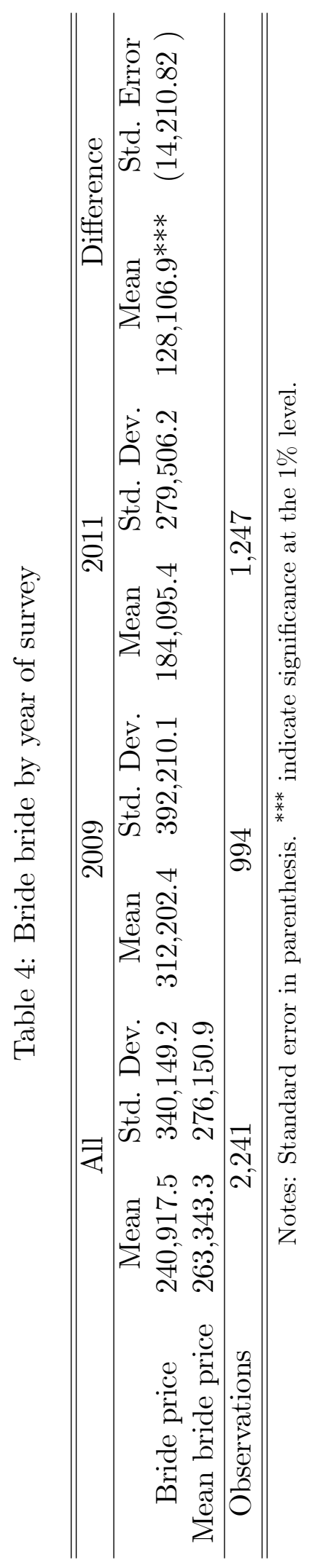


Table 5: Robustness checks: dependent variable is the mean bride price over the years

\begin{tabular}{|c|c|c|c|c|c|}
\hline & $(1)$ & $(2)$ & $(3)$ & $(4)$ & $(5)$ \\
\hline Mean bride price $(\log )$ & $\begin{array}{c}-0.084^{* *} \\
(0.034)\end{array}$ & $\begin{array}{c}-0.074^{* *} \\
(0.034)\end{array}$ & $\begin{array}{c}-0.087^{* *} \\
(0.032)\end{array}$ & $\begin{array}{c}-0.074^{* *} \\
(0.025)\end{array}$ & $\begin{array}{c}-0.069^{* *} \\
(0.023)\end{array}$ \\
\hline \multicolumn{6}{|l|}{ Characteristics of the wife } \\
\hline$\overline{\text { Age }}$ & $\begin{array}{c}0.501^{* * *} \\
(0.026)\end{array}$ & $\begin{array}{c}0.513^{* * *} \\
(0.026)\end{array}$ & $\begin{array}{c}0.500^{* * *} \\
(0.042)\end{array}$ & $\begin{array}{c}0.509^{* * *} \\
(0.041)\end{array}$ & $\begin{array}{c}0.443^{* * *} \\
(0.071)\end{array}$ \\
\hline Age square & $\begin{array}{c}-0.005^{* * *} \\
(0.000)\end{array}$ & $\begin{array}{c}-0.005^{* * *} \\
(0.000)\end{array}$ & $\begin{array}{c}-0.005^{* * *} \\
(0.000)\end{array}$ & $\begin{array}{c}-0.005^{* * *} \\
(0.000)\end{array}$ & $\begin{array}{c}-0.004^{* * *} \\
(0.001)\end{array}$ \\
\hline Age at marriage & $\begin{array}{c}-0.212^{* * *} \\
(0.061)\end{array}$ & $\begin{array}{c}-0.260^{* * *} \\
(0.064)\end{array}$ & $\begin{array}{c}-0.230^{* *} \\
(0.077)\end{array}$ & $\begin{array}{c}-0.282^{* * *} \\
(0.063)\end{array}$ & $\begin{array}{c}-0.264^{* *} \\
(0.082)\end{array}$ \\
\hline Age at marriage square & $\begin{array}{c}0.003^{* *} \\
(0.001)\end{array}$ & $\begin{array}{c}0.004^{* * *} \\
(0.001)\end{array}$ & $\begin{array}{c}0.003^{*} \\
(0.002)\end{array}$ & $\begin{array}{c}0.004^{* *} \\
(0.001)\end{array}$ & $\begin{array}{c}0.004^{* *} \\
(0.001)\end{array}$ \\
\hline Literacy & $\begin{array}{c}-0.272^{*} \\
(0.147)\end{array}$ & $\begin{array}{c}-0.322^{* *} \\
(0.145)\end{array}$ & $\begin{array}{l}-0.224 \\
(0.159)\end{array}$ & $\begin{array}{l}-0.274 \\
(0.166)\end{array}$ & $\begin{array}{l}-0.276 \\
(0.173)\end{array}$ \\
\hline \multicolumn{6}{|l|}{ Characteristics of the husband } \\
\hline$\overline{\text { Age }}$ & $\begin{array}{c}0.051^{*} \\
(0.029)\end{array}$ & $\begin{array}{c}0.046 \\
(0.029)\end{array}$ & $\begin{array}{c}0.051^{*} \\
(0.026)\end{array}$ & $\begin{array}{c}0.042 \\
(0.026)\end{array}$ & $\begin{array}{c}0.044 \\
(0.028)\end{array}$ \\
\hline Age square & $\begin{array}{l}-0.000 \\
(0.000)\end{array}$ & $\begin{array}{l}-0.000 \\
(0.000)\end{array}$ & $\begin{array}{c}-0.000^{*} \\
(0.000)\end{array}$ & $\begin{array}{l}-0.000 \\
(0.000)\end{array}$ & $\begin{array}{l}-0.000 \\
(0.000)\end{array}$ \\
\hline Literacy & $\begin{array}{c}0.092 \\
(0.110)\end{array}$ & $\begin{array}{c}0.182 \\
(0.111)\end{array}$ & $\begin{array}{c}0.047 \\
(0.227)\end{array}$ & $\begin{array}{c}0.103 \\
(0.227)\end{array}$ & $\begin{array}{c}0.099 \\
(0.220)\end{array}$ \\
\hline \multicolumn{6}{|l|}{ Household characteristics } \\
\hline Polygamous & & $\begin{array}{c}-0.077 \\
(0.120)\end{array}$ & & $\begin{array}{l}-0.115 \\
(0.142)\end{array}$ & $\begin{array}{c}-0.136 \\
(0.147)\end{array}$ \\
\hline Landownership & & & & & $\begin{array}{c}0.113^{* * *} \\
(0.026)\end{array}$ \\
\hline Observations & 2,241 & 2,241 & 2,241 & 2,241 & 2,241 \\
\hline Region dummies & No & No & Yes & Yes & Yes \\
\hline Survey year dummies & Yes & Yes & Yes & Yes & Yes \\
\hline Ethnicity, religion and caste & No & Yes & No & Yes & Yes \\
\hline Year of marriage cohort dummies & No & No & No & No & Yes \\
\hline
\end{tabular}

Notes: All regressions include a constant. Robust standard errors are in parenthesis. Standard errors are clustered at the region level in Columns 3 and $4 .{ }^{* * *},{ }^{* *},{ }^{*}$ indicate significance at the $1,5,10 \%$ level, respectively. 
Table 6: Bride price and fertility: Human capital and income of the wife and the husband

\begin{tabular}{|c|c|c|c|c|}
\hline & $(1)$ & $(2)$ & $(3)$ & $(4)$ \\
\hline \multicolumn{5}{|l|}{ Characteristics of the wife } \\
\hline$\overline{\text { Literacy }}$ & $\begin{array}{c}0.128 \\
(0.645)\end{array}$ & $\begin{array}{l}-0.293 \\
(0.170)\end{array}$ & $\begin{array}{l}-0.273 \\
(0.172)\end{array}$ & $\begin{array}{l}-0.280 \\
(0.173)\end{array}$ \\
\hline Bride price $\mathrm{x}$ Literacy & $\begin{array}{l}-0.066 \\
(0.044)\end{array}$ & & & \\
\hline Bride price $\mathrm{x}$ No literacy & $\begin{array}{c}-0.029 * \\
(0.013)\end{array}$ & & & \\
\hline Income gen. Activity (IGA) & & $\begin{array}{l}-0.505 \\
(0.318)\end{array}$ & & \\
\hline Bride price $\mathrm{x}$ IGA & & $\begin{array}{c}0.001 \\
(0.021)\end{array}$ & & \\
\hline Bride price $\mathrm{x}$ No IGA & & $\begin{array}{c}-0.066^{* *} \\
(0.021)\end{array}$ & & \\
\hline \multicolumn{5}{|l|}{ Characteristics of the husband } \\
\hline$\overline{\text { Literacy }}$ & $\begin{array}{c}0.102 \\
(0.218)\end{array}$ & $\begin{array}{c}0.093 \\
(0.219)\end{array}$ & $\begin{array}{c}0.969^{*} \\
(0.404)\end{array}$ & $\begin{array}{c}0.101 \\
(0.217)\end{array}$ \\
\hline Bride price $\mathrm{x}$ Literacy & & & $\begin{array}{c}-0.083^{* * *} \\
(0.014)\end{array}$ & \\
\hline Bride price $\mathrm{x}$ No literacy & & & $\begin{array}{l}-0.006 \\
(0.021)\end{array}$ & \\
\hline Income gen. Activity (IGA) & & & & $\begin{array}{c}0.163 \\
(0.621)\end{array}$ \\
\hline Bride price $\mathrm{x}$ IGA & & & & $\begin{array}{c}-0.037^{*} \\
(0.016)\end{array}$ \\
\hline Bride price $\mathrm{x}$ No IGA & & & & $\begin{array}{l}-0.028 \\
(0.050)\end{array}$ \\
\hline Observations & 2,241 & 2,241 & 2,241 & 2,241 \\
\hline Cohort, region and survey year dummies & Yes & Yes & Yes & Yes \\
\hline F-test (p-value) & 0.46 & 0.04 & 0.02 & 0.88 \\
\hline
\end{tabular}

All regressions include a constant and controls for ethnicity, religion, caste, polygamy, landownership, age variables of the wife and husband. Robust standard errors are in parenthesis. Standard errors are clustered at the region level. ${ }^{* * *},{ }^{* *},{ }^{*}$ indicate significance at 1 , $5,10 \%$ level, respectively. Detailed results available upon request. 
Table 7: Bride price and fertility: Economic conditions and wealth

\begin{tabular}{lcc}
\hline \hline & $(1)$ & $(2)$ \\
\hline Landownership & $0.163^{* * *}$ & $0.115^{* * *}$ \\
Bride price x Landownership & $(0.043)$ & $(0.027)$ \\
& $\left(0.042^{* *}\right.$ & \\
Bride price x No Landownership & -0.003 & \\
& $(0.025)$ & \\
Cohort [0, 5[ & & -0.393 \\
Cohort [5, 10[ & -1.002 \\
& 0.055 \\
Cohort [10, 15[ & $(0.728)$ \\
Cohort [15, 20[ & -0.379 \\
& -1.270 \\
Cohort [20, 25[ & -0.168 \\
& & $(0.589)$ \\
Bride price x Cohort [0, 5[ & & 0.759 \\
& & -1.375 \\
Bride price x Cohort [5, 10[ & -0.027 \\
& & $(0.041)$ \\
Bride price x Cohort [10, 15[ & & -0.034 \\
& & $(0.044)$ \\
Bride price x Cohort [15, 20[ & & 0.010 \\
& & $(0.053)$ \\
Bride price x Cohort [15, 20[ & & 0.008 \\
& & $(0.049)$ \\
& & -0.055 \\
Observations & & $0.089)$ \\
Region and survey year dummies & Yes & 2,241 \\
F-test (p-value) & Yes \\
\hline \hline
\end{tabular}

All regressions include a constant and controls for ethnicity, religion, caste, polygamy, age and literacy variables of the wife and husband. The reference group for the year of marriage cohorts is the cohort $[25,$.$] . Robust standard errors are in parenthesis.$ Standard errors are clustered at the region level. ${ }^{* * *},{ }^{* *},{ }^{*}$ indicate significance at 1, 5, 10\% level, respectively. Detailed results available upon request. 
Table 8: Bride price and fertility: Appreciation of the bride by the husband

\begin{tabular}{|c|c|c|c|}
\hline & $(1)$ & $(2)$ & $(3)$ \\
\hline Below 20 & $\begin{array}{l}-0.455 \\
(0.344)\end{array}$ & & \\
\hline Bride price $\mathrm{x}$ Below 20 & $\begin{array}{l}-0.015 \\
(0.019)\end{array}$ & & \\
\hline Bride price $\mathrm{x}$ Above 20 & $\begin{array}{c}-0.081^{* *} \\
(0.029)\end{array}$ & & \\
\hline Age distance & & $\begin{array}{c}0.046^{*} \\
(0.020)\end{array}$ & \\
\hline Age distance square & & $\begin{array}{c}-0.001^{* *} \\
(0.000)\end{array}$ & \\
\hline Bride price $\mathrm{x}$ High age distance & & $\begin{array}{c}-0.039 * * \\
(0.015)\end{array}$ & \\
\hline Bride price $\mathrm{x}$ No age distance & & $\begin{array}{l}-0.023 \\
(0.016)\end{array}$ & \\
\hline Divorce & & & $\begin{array}{c}0.383 \\
(0.977)\end{array}$ \\
\hline Bride price $\mathrm{x}$ divorce & & & $\begin{array}{c}-0.244 \\
(0.177)\end{array}$ \\
\hline Bride price $\mathrm{x}$ No divorce & & & $\begin{array}{l}-0.019 \\
(0.011)\end{array}$ \\
\hline Observations & 2,241 & 2,241 & 2,241 \\
\hline Cohort, region and survey year dummies & Yes & Yes & Yes \\
\hline F-test (p-value) & 0.16 & 0.06 & 0.23 \\
\hline
\end{tabular}

All regressions include a constant and controls for ethnicity, religion, caste, polygamy, landownership, age and literacy variables of the wife and husband. Robust standard errors are in parenthesis. Standard errors are clustered at the region level. ${ }^{* * *},{ }^{* *},{ }^{*}$ indicate significance at 1, 5, 10\% level, respectively. Detailed results available upon request. 
Table 9: Bride price and fertility: Household context

\begin{tabular}{|c|c|c|c|}
\hline & (1) & (2) & (3) \\
\hline \multirow[t]{2}{*}{ Polygamy } & $1.171^{* * *}$ & -0.303 & -0.141 \\
\hline & $(0.304)$ & $(0.586)$ & $(0.147)$ \\
\hline \multirow[t]{2}{*}{ Bride price $\mathrm{x}$ polygamy } & $-0.291^{* *}$ & & \\
\hline & $(0.102)$ & & \\
\hline \multirow[t]{2}{*}{ Bride price $\mathrm{x}$ No polygamy } & -0.015 & & \\
\hline & $(0.008)$ & & \\
\hline \multicolumn{4}{|l|}{ Rank of the wife in polygamous household } \\
\hline \multirow[t]{2}{*}{ First wife } & & 0.448 & \\
\hline & & $(0.605)$ & \\
\hline \multirow[t]{2}{*}{ Second wife } & & 0.601 & \\
\hline & & -1.042 & \\
\hline \multirow[t]{2}{*}{ Third or fourth wife } & & 0.580 & \\
\hline & & -1.199 & \\
\hline \multirow[t]{2}{*}{ Bride price $\mathrm{x}$ First wife } & & -0.020 & \\
\hline & & $(0.069)$ & \\
\hline \multirow[t]{2}{*}{ Bride price $\mathrm{x}$ Second wife } & & -0.041 & \\
\hline & & $(0.057)$ & \\
\hline \multirow[t]{2}{*}{ Bride price $\mathrm{x}$ Third or fourth wife } & & -0.087 & \\
\hline & & $(0.075)$ & \\
\hline \multirow[t]{2}{*}{ Distance to wife's parents } & & & 0.000 \\
\hline & & & $(0.001)$ \\
\hline \multirow[t]{2}{*}{ Bride price $\mathrm{x}$ Distance to wife's parents } & & & -0.042 \\
\hline & & & $(0.029)$ \\
\hline \multirow[t]{2}{*}{ Bride price $x$ No distance to wife's parents } & & & -0.003 \\
\hline & & & $(0.003)$ \\
\hline \multirow[t]{2}{*}{ Distance to husband's parents } & & & $0.003^{*}$ \\
\hline & & & $(0.001)$ \\
\hline \multirow[t]{2}{*}{ Bride price $\mathrm{x}$ Distance to husband's parents } & & & $-0.400^{* *}$ \\
\hline & & & $(0.155)$ \\
\hline \multirow[t]{2}{*}{ Bride price x No distance to husband's parents } & & & $-0.036^{* *}$ \\
\hline & & & $(0.013)$ \\
\hline Observations & 2,241 & 2,241 & 2,241 \\
\hline Cohort, regions and survey year dummies & Yes & Yes & Yes \\
\hline F-test (p-value )distance to wife's parents & 0.03 & 0.88 & 0.19 \\
\hline F-test (p-value) distance to husband's parents & & & 0.04 \\
\hline
\end{tabular}

All regressions include a constant and controls for ethnicity, religion, caste, polygamy, landownership, age and literacy variables of the wife and husband. Robust standard errors are in parenthesis. Standard errors are clustered at the region level. ${ }^{* * *},{ }^{* *},{ }^{*}$ indicate significance at 1, 5, 10\% level, respectively. Detailed results available upon request. 